\title{
Evaluation of mortar properties obtained through partial substitution of Portland cement by ashes of oil palm empty fruit bunch
}

\section{(Avaliação das propriedades de argamassas obtidas através da substituição parcial do cimento Portland por cinzas de engaço de dendê)}

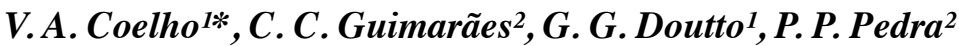 \\ ${ }^{1}$ Universidade Federal do Recôncavo da Bahia, Graduação em Engenharia Civil, R. Rui Barbosa 710, \\ 44380-000, Cruz das Almas, BA, Brazil \\ ${ }^{2}$ Universidade Federal do Recôncavo da Bahia, Centro de Ciências Exatas e Tecnológicas, \\ Cruz das Almas, BA, Brazil
}

\begin{abstract}
Currently, palm oil is a leader in production and consumption among commercial edible oils, with a growing world production that exceeds 66 million tons per year. It is estimated that the generation of residues from the burning of palm oil empty fruit bunches as fuel in the boilers corresponds to $5 \%$ in mass of the total of oil extracted. This work evaluated the mechanical properties resulting from the use of the empty fruit bunch ashes as a partial substitute of Portland cement in mortars in different contents in 1:3 and 1:6 mixes. Mortars obtained with the use of ash presented greater deformability, implying greater workability. The results obtained pointed to potential use of the ash as filler in mortars without loss on compressive strength for contents up to 10\% in the 1:3 mix and $5 \%$ in the 1:6 mix. It was observed an increase in the void index and the water absorption capacity, with a proportional reduction of the flexural strength.
\end{abstract}

Keywords: oil palm empty fruit bunch ash, agroindustry waste, mortar.

\section{Resumo}

Atualmente, o óleo de palma é líder em produção e consumo dentre os óleos comestíveis comercializados, com uma produção mundial que ultrapassa 66 milhões de toneladas anuais. Estima-se que a produção de resíduo da queima do engaço do dendê como combustível nas caldeiras corresponde a $5 \%$ em massa do total de óleo extraído. Este trabalho avaliou as propriedades mecânicas resultantes do uso da cinza do engaço como substituto parcial do cimento Portland em argamassas com diferentes teores nos traços 1:3 e 1:6. As argamassas obtidas apresentaram maior deformabilidade, implicando em uma maior trabalhabilidade. Os resultados obtidos apontaram para um potencial uso da cinza como fíler em argamassas sem prejuízo da resistência à compressão para teores de até 10\% no traço 1:3 e 5\% no traço 1:6. Foi observado um aumento no índice de vazios e na capacidade de absorção de água, com redução proporcional da resistência à tração na flexão.

Palavras-chave: cinza de engaço de dendê, resíduos agroindustriais, argamassa.

\section{INTRODUCTION}

As the second most used resource by humans, Portland cement is a fundamental material for the socioeconomic development [1]. In Brazil, about 57.4 million tons were produced in 2016 according to the Sindicato Nacional da Indústria do Cimento - SNIC (National Union of Cement Industry). It is known that in addition to high energy consumption, the cement manufacturing process degrades areas for raw material extraction and releases approximately one ton of $\mathrm{CO}_{2}$ into the atmosphere for each ton of cement produced [2]. Seeking a better relationship with the environment, especially with regard to long-term effects, researches for alternative sources of raw materials for the

*(D) https://orcid.org/0000-0003-3595-9433 construction sector have been stimulated, one of which is the use of industrial waste such as fibers and ashes of agribusiness [3-8].

Currently, palm oil is the leader in production and consumption among the main commercial edible oils, with an increasing world production that already surpasses 66 million metric tons annually [9]. Brazil, which ranks $12^{\text {th }}$ among the largest producers of palm oil, registered in 2016 a production of more than 1.6 million metric tons of bunches [10], with an expansion tendency evidenced by the growing demand for seeds in the internal market [11]. Despite having as the main product the palm oil (extracted from the fruit mesocarp) and the palm kernel oil (extracted from the kernel) for food purposes, palm oil industry provides material for several other applications such as the production of biofuels, pharmaceuticals, cosmetics and cleaning. The productive process generates a large amount of solid waste that raises 
environmental and economic discussions on ways to reuse these by-products and amortize environmental impacts [12]. It is estimated that, from the total material that arrives to be processed in the industry, $20 \%$ corresponds to the production of crude palm oil and $1.5 \%$ to palm kernel oil. The empty fruit bunch represents between $20 \%$ and $25 \%$ of this total [12-14], which would correspond to 16.5 million tons of empty fruit bunch as residue worldwide each year. Due to the enormous volume of this residue, new alternatives for its disposal have been sought. The main reuse is in the crops as a source of organic matter $[15,16]$ or as biomass to obtain electric energy or feed the boilers in the process of oil extraction $[17,18]$, resulting in the production of large amounts of ash (about $5 \%$ by mass), which are normally disposed in landfills $[19,20]$.

The use of ash in Portland cement products is known to have good results both because of the pozzolanic properties within many of these ashes, which, when reacted with the calcium hydroxide present in the cement matrix, produce compounds that increase the strength and durability of the material, and the chemically inert effect of filling voids, where the ash particles occupy the spaces left by other larger particles and improve the packaging of the mortar grains, promoting greater compaction of the composite. Currently, several studies are being conducted about the properties of composites formed by the partial replacement of Portland cement by ash from rice hulls, sugar cane bagasse ash and fly ash, for example $[2,17,20,21]$. The use of ashes from the palm oil industry in cement products has been mainly studied in applications related to concrete properties. However, attention should be given to the fact that different industries produce ash with varying characteristics depending on their burning process and especially the composition and proportion of the materials used as biomass [22,23]. The use of palm oil empty fruit bunch ash (POEFBA) in cementitious compounds is still little explored [18, 24]. Most of the studies in the field are related to the use of ash resulting from the burning of palm oil fiber, shell and kernel due to the great use of these by-products as biomass for boiler feed in the leading production countries such as Malaysia and Thailand [6, 17, 19, 25-27]. In this way, this work sought to evaluate the mortar properties obtained with the partial substitution of Portland cement by POEFBA, obtained in oil palm extraction industry in the State of Bahia, Brazil, in contents of $5 \%, 10 \%$ and $15 \%$ in mass.

\section{EXPERIMENTAL}

POEFBA was obtained through the use of empty fruit bunches as fuel for a boiler in the palm oil extracting process by the industry OLDESA - Óleo de Dendê, in the city of Nazaré, Brazil. The industry estimate of ash production is about 30 tons per week. The high amount of crude ash removed from the boiler was grouped in a pile, having a dark coloration due to the unburned organic matter, containing also some empty fruit bunch fibers and clumps of variable shape. The collected material was then ground in a ball mill for 15 min to standardize the grains and burned in a muffle at $700{ }^{\circ} \mathrm{C}$ until all the combustible material was removed, acquiring a gray color. At this stage, a fire loss of approximately $50 \%$ in mass was observed. The resulting material was again ground in a ball mill for $90 \mathrm{~min}$ for the production of finer granulometry due to laboratory limitations for better granulometric characterization.

The specific mass of the POEFBA was determined using a procedure similar to that described in NBR NM 52 [28]. The water was replaced by kerosene due to the possible solubility of the ash in water and a value of $2.63 \mathrm{~g} / \mathrm{cm}^{3}$ was found. The pozzolanic performance index of POEFBA with Portland cement at 28 days was determined according to NBR 5752 [29] as $68.1 \%$. The $\mathrm{pH}$ of the ash was determined in distilled water with a digital $\mathrm{pH}$ meter with a resolution of 0.01 . For this, three measurements were carried out in solutions of $20 \mathrm{~mL}$ of water with the addition of $5 \%, 10 \%$ and $15 \%$ of ash in mass, obtaining an average $\mathrm{pH}$ of 11.01 . The same analysis was done with Portland cement, obtaining an average $\mathrm{pH}$ of 12.07 . The X-ray diffraction (XRD) analysis of the ash, whose pattern is presented in Fig. 1, indicated the presence of $\mathrm{SiO}_{2}$ peaks, with amorphous halo between the values of $20^{\circ}$ and $35^{\circ}(2 \theta)$, indicating a potential pozzolanic activity of the material, similar to that recorded in $[27,30$, 31].

The fine aggregate used was a washed sand commercialized in the municipality of Cruz das Almas, Bahia, Brazil, dried in the oven, with a characteristic size of $2.4 \mathrm{~mm}$, fineness modulus of 2.92 and a grain size curve presented in Fig. 2, according to the procedures of NBR NM 248 [32] with the characterization ranges of NBR 7211 [33]. The cement used was the CP-V ARI, which had no pozzolanic mineral additions, with a specific mass of $3.08 \mathrm{~g} /$ $\mathrm{cm}^{3}$. The water used in the preparation of the mortars, curing and testing specimens was obtained from the municipal supply system.

The study was carried out with the partial replacement of Portland cement by POEFBA at $0 \%$ (reference), $5 \%, 10 \%$ and $15 \%$ by mass in the mixes of $1: 3$ and $1: 6$. The mortars were prepared in a vertical axis electromechanical mortar

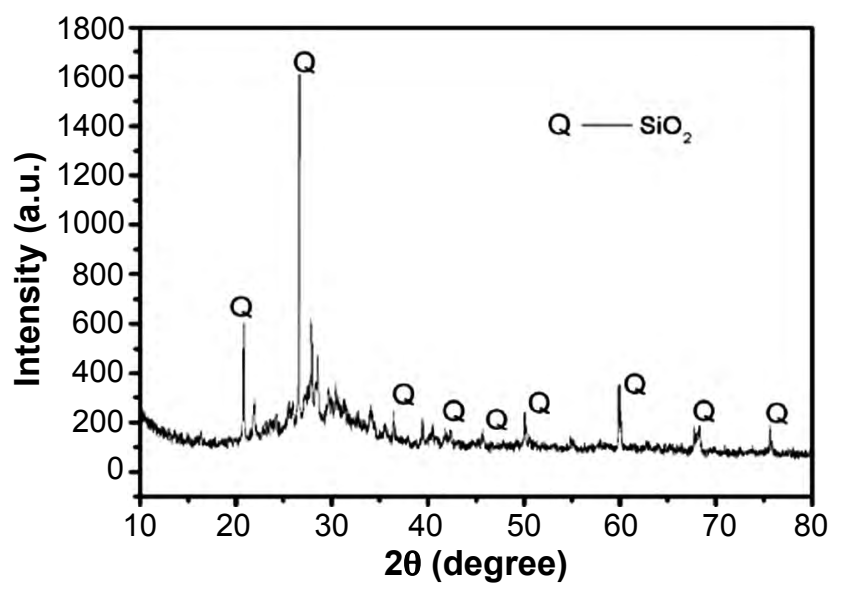

Figure 1: XRD pattern of the ash.

[Figura 1: Padrão de DRX da cinza.] 

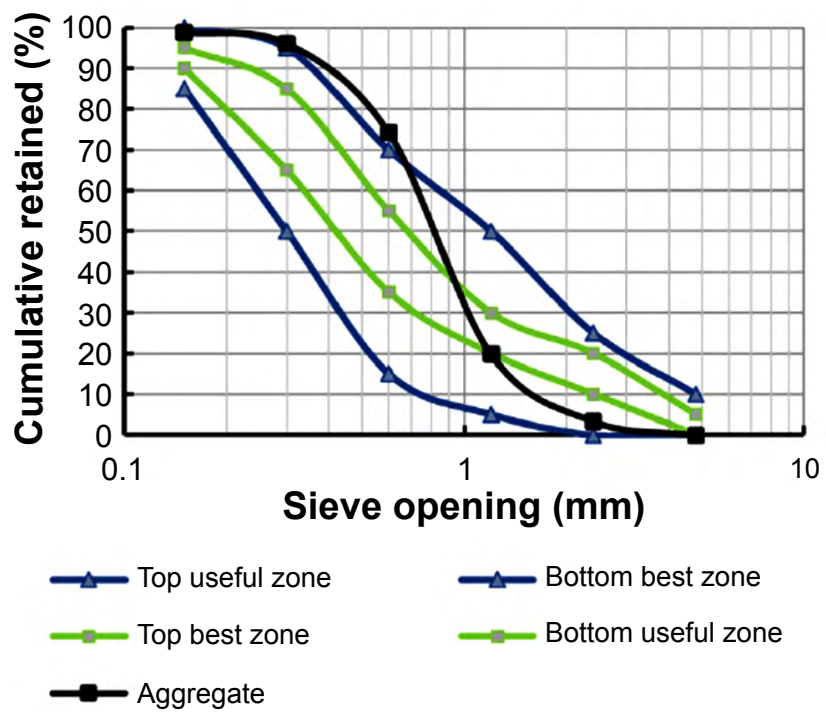

Figure 2: Particle size curve of the fine aggregate.

[Figura 2: Curva granulométrica do agregado miúdo.]

mixer with a digital controller. Table I presents a summary of the proportion of materials used in each mortar and identification of the analysis groups. The water/binder ratio was defined based on the consistency test (NBR 13276 [34]) for spreading of $250 \pm 10 \mathrm{~mm}$ with the reference group; it was observed the influence of the POEFBA on the workability of the mortars according to the variation of the spreading in groups with substitution. Thus, the ratio was set at 0.52 for the $1: 3$ mix and 0.9 for the $1: 6$ mix.

Table I - Materials proportion of mortars.

[Tabela I - Proporção dos materiais das argamassas.]

\begin{tabular}{ccccc}
\hline Content & Group & $\begin{array}{c}\text { Cement } \\
(\mathrm{g})\end{array}$ & $\begin{array}{c}\text { POEFBA } \\
(\mathrm{g})\end{array}$ & $\begin{array}{c}\text { Sand } \\
(\mathrm{g})\end{array}$ \\
\hline \multicolumn{5}{c}{$1: 3 \mathrm{mix}$} \\
$0 \%$ & 3REF & 624.0 & 0.0 & 1872.0 \\
$5 \%$ & 3PA5 & 592.8 & 31.2 & 1872.0 \\
$10 \%$ & 3PA10 & 561.6 & 62.4 & 1872.0 \\
$15 \%$ & 3PA15 & 530.4 & 93.6 & 1872.0 \\
\hline & & $1: 6 \mathrm{mix}$ & & \\
$0 \%$ & 6REF & 312.0 & 0.0 & 1872.0 \\
$5 \%$ & 6PA5 & 296.4 & 15.6 & 1872.0 \\
$10 \%$ & 6PA10 & 280.8 & 31.2 & 1872.0 \\
$15 \%$ & 6PA15 & 265.2 & 46.8 & 1872.0 \\
\hline
\end{tabular}

The water absorption properties, void index (NBR 9778 [35]), flexural strength (NBR 13279 [36]) and compressive strength (NBR 7215 [37]) were evaluated. It was also evaluated the influence of POEFBA on the carbonation of mortars by exposing 5 cylindrical specimens of each content to a controlled environment, with a carbon dioxide concentration of $90 \%$ and relative humidity of $85 \%$ [38]. After 3 days of seasoning under ambient conditions, the
1:3 mix samples were subjected to accelerated carbonation for 14 days and the 1:6 mix for 7 days. After the exposure, the specimens were fractured diametrically and the carbonation advance was measured with a digital caliper, with a resolution of $0.01 \mathrm{~mm}$, by spraying phenolphthalein solution on the newly exposed surfaces. The results of the tests, with the exception of the consistency index, followed the sampling procedure described by NBR 7215 [37] with further statistical analysis of variance (ANOVA) with the ash content as the variation factor. The averages obtained were also compared by Tukey's test with a significance level of $5 \%$. Statistical calculations were performed in the PAST software [39].

\section{RESULTS AND DISCUSSION}

Table II presents the average values of the consistency index of the mortars. It was observed that the increase of ash content progressively increased the consistency index of the 1:3 mix, presenting a maximum variation in relation to the reference of $8.3 \%$. However, the variation of ash content in the 1:6 mix resulted in a maximum variation of $0.75 \%$, almost not differing independently of the content employed. The observed behavior showed that the use of POEFBA increased the consistency index of mortars, a parameter directly related to its workability. Morphological analyzes carried out in similar studies with other ashes of the palm industry point to a relatively spherical shape of these materials, which would favor the reduction of the internal friction between the constituent particles of the mortars and thus the increase in its deformability, as observed in the increase of the consistency index [19, 23, 26]. It was also observed that this effect was reduced in the 1:6 mix, since the dilution of binder in relation to the fine aggregate minimized the granulometric influence of the POEFBA in the mixture.

Table II - Consistency index of mortars. [Tabela II - Índice de consistência das argamassas.]

\begin{tabular}{cccc}
\hline Group & $\begin{array}{r}\text { Consistency } \\
\text { index }(\mathrm{mm})\end{array}$ & Group & $\begin{array}{r}\text { Consistency } \\
\text { index (mm) }\end{array}$ \\
\hline \multicolumn{2}{c}{$1: 3$ mix } & \multicolumn{2}{c}{$1: 6$ mix } \\
3REF & 253 & $6 \mathrm{REF}$ & 264 \\
3PA5 & 258 & $6 \mathrm{PA} 5$ & 265 \\
3PA10 & 274 & $6 \mathrm{PA} 10$ & 266 \\
3PA15 & 270 & 6PA15 & 265 \\
\hline
\end{tabular}

The compressive strength results are presented in Table III for the 1:3 and 1:6 mixes. For interpretation of the statistical analysis, it is observed that the P-value lower than 0.05 indicates the existence of significant variation between at least one pair of means. The Tukey's test result is indicated by letters next to the mean values of the tables, and means with equal letters do not differ significantly from each other at $5 \%$ probability. For the 1:3 mix, the analysis of variance 
showed a significant difference between at least one of the evaluated groups, identified through the Tukey's test as being the 3PA15 group. In this way, it can be affirmed that the substitution of Portland cement with POEFBA in contents of up to $10 \%$ did not affect significantly the compressive strength in this mix. Similarly, it was observed that the use of POEFBA at contents of up to $5 \%$ also did not significantly affect the compressive strength in the 1:6 mix. It was observed that the increase in the levels of POEFBA in the $1: 3$ mix resulted in a reduction of $14.7 \%$ in the 3PA15 group. For the 1:6 mix, a $20.2 \%$ reduction was observed in 6PA10 and $9.5 \%$ reduction in 6PA15. Due to the low pozzolanic activity of POEFBA with Portland cement at 28 days (68.1\%) it can be inferred that the production of secondary C-S-H gel from the pozzolanic reactions at this stage was not enough to compensate for the dilution effect of Portland cement, which contributed to the observed tendency of reduction of compressive strength values $[24,26]$. However, similar to that observed in [40], the filler effect of the ash particles, capable of occupying the voids of the material and favoring the packaging of the grains, alleviated the loss of resistance, giving small variations in groups 3PA5, 3PA10 and 6PA5 in relation to the respective reference groups. As explained in [40], the ingress of particles larger than the voids in the matrix impairs the packaging effect and favors the increase of porosity, so there is a maximum ash content for which the filler effect can act in an expressive way in the attenuation of the loss of resistance when added to the dilution of Portland cement. This phenomenon justifies the continuous reduction of property values for substitution contents greater than those mentioned above.

The values of flexural strength are presented in Table IV for the 1:3 and 1:6 mixes. The increase in POEFBA content in the mortars led to a tendency of reduction in the values

Table III - Compressive strength at 28 days of mortars.

[Tabela III - Resistência à compressão axial aos 28 dias das argamassas.]

\begin{tabular}{cccc}
\hline Group & $\begin{array}{c}\text { Compressive } \\
\text { strength } \\
(\mathrm{MPa})\end{array}$ & $\begin{array}{c}\text { Standard } \\
\text { deviation } \\
(\mathrm{MPa})\end{array}$ & $\begin{array}{c}\text { Coefficient } \\
\text { of variation } \\
(\%)\end{array}$ \\
\hline 3REF & $33.4^{\mathrm{A}}$ & 1.8 & 5.39 \\
3PA5 & $32.1^{\mathrm{A}}$ & 0.2 & 0.62 \\
3PA10 & $31.6^{\mathrm{A}}$ & 0.9 & 2.85 \\
3PA15 & $28.5^{\mathrm{B}}$ & 0.5 & 1.75 \\
\multicolumn{5}{c}{$1: 6 \mathrm{mix}$} \\
6REF & $11.64^{\mathrm{A}}$ & 0.37 & 3.18 \\
6PA5 & $11.10^{\mathrm{A}}$ & 0.28 & 2.52 \\
6PA10 & $9.29^{\mathrm{B}}$ & 0.08 & 0.86 \\
6PA15 & $10.54^{\mathrm{A}}$ & 0.41 & 3.89 \\
\multicolumn{5}{c}{ P-value } & \multicolumn{2}{c}{0.00262} \\
\hline
\end{tabular}

of flexural strength in both mixes. In the 1:3 mix, the use of POEFBA resulted in a reduction in flexural strength in $6.9 \%$ in the 3PA5 group, $17.8 \%$ in the 3PA10 and $18.2 \%$ in the 3PA15. For the 1:6 mix there was a reduction of $5.8 \%$ in the 6PA5 group, $28.2 \%$ in the 6PA10 and $35.5 \%$ in the 6PA15. Based on the analysis of variance and Tukey's test result, the influence of POEFBA on the flexural strength of the mortars was significant in all the verified substitution levels, being another indication of the potential of the POEFBA as filler material, once that materials with agglomerating behavior tend to maintain or even increase flexural strength at the age of 28 days [41]. The reduction of the flexural strength of the mortars can be explained by the low pozzolanic activity of the POEFBA at 28 days, such that, possibly, no binder compounds were produced in sufficient quantity to compensate the dilution effect of the Portland cement [19]. Furthermore, because it is not a fibrous material, the POEFBA was unable to anchor the cracks resulting from tensile stresses, which contributed to the results obtained. Similar behaviors were observed with other ashes from the agroindustry, with a tendency to recover the tensile strength in flexure at higher ages (90 and 180 days) due to the production of binder compounds by late pozzolanic reaction of some of these materials $[17,19]$.

Table IV - Flexural strength at 28 days of mortars. [Tabela IV - Resistência à tração na flexão aos 28 dias das argamassas.]

\begin{tabular}{|c|c|c|c|}
\hline Group & $\begin{array}{c}\text { Flexural } \\
\text { strength } \\
(\mathrm{MPa})\end{array}$ & $\begin{array}{c}\text { Standard } \\
\text { deviation } \\
(\mathrm{MPa})\end{array}$ & $\begin{array}{c}\text { Coefficient } \\
\text { of variation } \\
(\%)\end{array}$ \\
\hline \multicolumn{4}{|c|}{ 1:3 mix } \\
\hline 3REF & $4.78^{\mathrm{A}}$ & 0.17 & 3.56 \\
\hline 3PA5 & $4.45^{\mathrm{B}}$ & 0.07 & 1.57 \\
\hline 3PA10 & $3.83^{\mathrm{C}}$ & 0.06 & 1.53 \\
\hline 3PA15 & $3.91^{\mathrm{D}}$ & 0.10 & 2.56 \\
\hline \multicolumn{2}{|c|}{ P-value } & \multicolumn{2}{|c|}{$<0.001$} \\
\hline \multicolumn{4}{|c|}{$1: 6 \mathrm{mix}$} \\
\hline $6 \mathrm{REF}$ & $2.59^{\mathrm{A}}$ & 0.06 & 2.32 \\
\hline 6PA5 & $2.44^{\mathrm{B}}$ & 0.08 & 3.33 \\
\hline 6PA10 & $1.86^{\mathrm{C}}$ & 0.05 & 2.69 \\
\hline 6PA15 & $1.67^{\mathrm{D}}$ & 0.005 & 0.25 \\
\hline \multicolumn{2}{|c|}{ P-value } & \multicolumn{2}{|c|}{$<0.001$} \\
\hline
\end{tabular}

The results of the variation of the void index for the $1: 3$ and 1:6 mixes are presented in Table $\mathrm{V}$. The analysis of variance showed that the influence of POEFBA on the void index of the mortars was significant in relation to the reference for both mixes. However, it was observed, based on the Tukey's test, that for the 1:3 mix there was no significant variation of the void index between groups 3PA5 and 3PA10. Similarly, it was observed that there was no expressive variation of the void index among the groups with POEFBA in the 1:6 mix. 
It was observed a proportional increase of the void index with the addition of POEFBA in the mortar matrices. The increase observed in relation to the reference was 3.8\% in the 3PA5 group, $3.6 \%$ in the 3PA10 and $6.4 \%$ in the 3PA15. For the $1: 6 \mathrm{mix}$, there were increases in relation to the reference of $3.4 \%, 2.7 \%$ and $4.0 \%$ in groups 6PA5, 6PA10 and 6PA15, respectively. The increase in the void index suggested that POEFBA mortars had a more porous nature, similar to that reported in $[18,19,30]$. Such behavior can be explained by the probable porosity of the grains of the ash, similar to that found in $[26,42,43]$ when they analyzed other ashes of the palm oil industry.

Table V - Void index of mortars. [Tabela $V$ - Índice de vazios das argamassas.]

\begin{tabular}{cccc}
\hline Group & $\begin{array}{c}\text { Void } \\
\text { index (\%) }\end{array}$ & $\begin{array}{c}\text { Standard } \\
\text { deviation (\%) }\end{array}$ & $\begin{array}{c}\text { Coefficient of } \\
\text { variation (\%) }\end{array}$ \\
\hline \multicolumn{5}{c}{$1: 3$ mix } \\
3REF & $17.11^{\mathrm{A}}$ & 0.19 & 1.11 \\
3PA5 & $17.76^{\mathrm{B}}$ & 0.23 & 1.30 \\
3PA10 & $17.72^{\mathrm{B}}$ & 0.31 & 1.75 \\
3PA15 & $18.20^{\mathrm{C}}$ & 0.13 & 0.71 \\
\multicolumn{5}{c}{ P-value } & $1: 6$ mix & \\
6REF & $19.83^{\mathrm{A}}$ & 0.08 & 0.40 \\
6PA5 & $20.51^{\mathrm{B}}$ & 0.21 & 1.02 \\
6PA10 & $20.36^{\mathrm{B}}$ & 0.20 & 0.98 \\
6PA15 & $20.64^{\mathrm{B}}$ & 0.19 & 0.92 \\
\multicolumn{6}{c}{ P-value }
\end{tabular}

The results of the water absorption rate are shown in Table VI. The analysis of variance indicated that the increase in the rates of absorption by immersion was significant in relation to the reference for both mixes analyzed. However, the variation was not significant according to Tukey's test between groups 3PA5 and 3PA10, as well as between groups 6PA5 and 6PA10. It was observed that the increase of POEFBA content in mortars increased their absorption rates. In the 1:3 mix there was an increase of $4.5 \%$ in the 3PA5 group, $3.9 \%$ in the $3 \mathrm{PA} 10$ and $7.3 \%$ in the 3PA15 group. For groups $1: 6$, increases of $2.7 \%, 2.3 \%$ and $4.4 \%$ were noticed in groups 6PA5, 6PA10 and 6PA15, respectively. The absorption rate followed a behavior similar to the void index, being direct the relation between these parameters. The observed tendency was similar to that reported in $[18$, 19, 30].

Table VII presents the average carbonation depth results. During the execution of the tests, it was observed that the samples of group 3PA5 were improperly positioned in the carbonation chamber, which compromised the validity of the average depth obtained and explained their anomalous behavior compared to the other groups analyzed. The analysis of variance pointed to a significant influence of
Table VI - Absorption rate of mortars. [Tabela VI - Taxa de absorção das argamassas.]

\begin{tabular}{lccc}
\hline Group & $\begin{array}{c}\text { Absorption } \\
\text { rate } \\
(\%)\end{array}$ & $\begin{array}{c}\text { Standard } \\
\text { deviation } \\
(\%)\end{array}$ & $\begin{array}{c}\text { Coefficient of } \\
\text { variation } \\
(\%)\end{array}$ \\
\hline \multirow{3}{*}{$1: 3$ mix } \\
3REF & $8.36^{\mathrm{A}}$ & 0.10 & 1.20 \\
3PA5 & $8.74^{\mathrm{B}}$ & 0.12 & 1.37 \\
3PA10 & $8.69^{\mathrm{B}}$ & 0.16 & 1.84 \\
3PA15 & $8.97^{\mathrm{C}}$ & 0.07 & 0.78 \\
\multicolumn{5}{c}{$<0.001$} \\
PREF & $10.21^{\mathrm{A}}$ & 0.06 & 0.59 \\
6PA5 & $10.49^{\mathrm{B}}$ & 0.08 & 0.76 \\
6PA10 & $10.45^{\mathrm{B}}$ & 0.11 & 1.05 \\
6PA15 & $10.66^{\mathrm{C}}$ & 0.10 & 0.94 \\
\multicolumn{5}{c}{ P-value } & $<0.001$ \\
\hline
\end{tabular}

POEFBA on the depth of carbonation of mortars. However, for the 1:3 mix, there was no expressive variation between the groups analyzed at the 5\% probability level by the Tukey's test. For the 1:6 mix, the same test showed that there was no significant variation between the groups that have POEFBA. A tendency to increase the average depth of carbonation in relation to the reference with the increase of the ash content employed was observed in 1:6 mix, which was statistically non-existent in the 1:3 mix. The carbonation test provides important data on the resistance of mortar to the penetration of aggressive agents, focusing on the permeability to carbon dioxide. The increase in void index and absorption rate indicated that POEFBA mortars were relatively more porous,

Table VII - Average depths of carbonation of mortars.

[Tabela VII - Profundidades médias de carbonatação das argamassas.]

\begin{tabular}{cccc}
\hline Group & $\begin{array}{c}\text { Carbonation } \\
\text { depth }(\mathrm{mm})\end{array}$ & $\begin{array}{c}\text { Standard } \\
\text { deviation }(\mathrm{mm})\end{array}$ & $\begin{array}{c}\text { Coefficient of } \\
\text { variation }(\%)\end{array}$ \\
\hline \multicolumn{5}{c}{$1: 3 \mathrm{mix}$} \\
3REF & $2.19^{\mathrm{A}}$ & 0.41 & 18.72 \\
3PA5 & $1.43^{*}$ & 0.32 & 22.38 \\
3PA10 & $2.46^{\mathrm{A}}$ & 0.34 & 13.82 \\
3PA15 & $2.76^{\mathrm{A}}$ & 0.34 & 12.32 \\
\multicolumn{5}{c}{ P-Value } & $1: 6$ mix & \\
6REF & $3.08^{\mathrm{A}}$ & 0.77 & 25.00 \\
6PA5 & $3.68^{\mathrm{AB}}$ & 0.56 & 15.21 \\
6PA10 & $4.36^{\mathrm{B}}$ & 0.77 & 17.66 \\
6PA15 & $4.11^{\mathrm{B}}$ & 0.62 & 15.08 \\
\multicolumn{6}{c}{ P-Value } & 0.046 \\
\hline \multicolumn{5}{c}{}
\end{tabular}


a hypothesis confirmed by the higher carbonation depths obtained. Nevertheless, the advance of the carbonation front is also associated with the chemical capacity of the matrix in hindering the advance of $\mathrm{CO}_{2}$, which depends on its $\mathrm{pH}$. The lower availability of alkaline hydrated compounds capable of reacting with carbon dioxide due to the dilution of Portland cement added to the lower $\mathrm{pH}$ presented by ash compared to cement contributed to the observed increase of the carbonation depth although the influence of POEFBA in the porosity of the material was small.

\section{CONCLUSIONS}

The effects of the substitution of Portland cement by palm oil empty fruit bunch ash (POEFBA) were more evident in the trace with higher concentration of binder, being possible to infer that: i) it was possible to substitute up to $10 \%$ of the Portland cement with POEFBA in the 1:3 mix and $5 \%$ in the 1:6 mix without significant variations in the compressive strength of the mortar at 28 days; ii) the increase of POEFBA content led to a gradual reduction of mortars' tensile strength; iii) the use of POEFBA increased the void index and the water absorption rate of the mortars in relation to the respective references, however, there was no significant variation of these properties between the contents with $5 \%$ and $10 \%$ of substitution in both mixes; iv) higher carbonation depths were observed with the increase of the POEFBA content in the mortars, indicating an increase in the permeability to carbon dioxide and possible reduction of the matrix's $\mathrm{pH}$; v) the use of POEFBA improved the workability of mortars in richer mixes, and its influence was minimized as the concentration of binder was reduced in relation to the amount of aggregate; vi) the pozzolanic performance index of the studied ash was close to that of a natural pozzolan, which, together with the XRD analysis, showed the need for more in-depth studies on the grain size and ash calcination method to evaluate the possibility of increasing its reactivity and improve the effects of its use on cementitious products.

\section{ACKNOWLEDGMENTS}

We are thankful to CNPq and the Federal University of Recôncavo da Bahia for the research grant and all the support in the development of the study. To OLDESA Óleo de Dendê Ltda. for the reception, waste provision and collaboration with the research.

\section{REFERENCES}

[1] L.I. Tosta, A.C. de Souza, R.J. da Silva, in Anais Congr. Ass. Bras. Eng. Produç., Foz do Iguaçu (2007) TR650480_0311.

[2] T.R. de Castro, C.H. Martins, Amb. Constr. 16, 3 (2016) 137.

[3] K.H. Or, A. Putra, M.Z. Selamat, Appl. Acoust. 119 (2017) 9.
[4] M.Z. Jumaat, U.J. Alengaram, H. Mahmud, Mater. Des. 30 (2009) 2227.

[5] R.H. Kupaei, U.J. Alengaram, M.Z.B. Jumaat, H. Nikraz, Constr. Build. Mater. 43 (2013) 490.

[6] M.A. Salih, A.A.A. Ali, N. Farzadnia, Constr. Build. Mater. 65 (2014) 592.

[7] P. Shafigh, H.B. Mahmud, M.Z.B. Jumaat, R. Ahmmad, S. Bahri, J. Clean. Prod. 80 (2014) 187.

[8] C. de Andrade, V. Mynrine, D.A. da Silva, S.L.S. Mayer, R. Simetti, F. Marchiori, Rev. Matér. 21, 2 (2016) 321.

[9] USDA, "Oilseeds: world markets and trade, 10.12.2017" (2017).

[10] IBGE, “Tabela 1613 - Área destinada à colheita, área colhida, quantidade produzida, rendimento médio e valor da produção das lavouras permanentes" (2016).

[11] K.F.G. Monteiro, A.K.O. Homma, Observatorio de la Economía Latinoamericana (2017).

[12] J. Furlan Júnior, Embrapa Amazônia Oriental, Documentos 246 (2006).

[13] J. Furlan Júnior, R.F. de Oliveira, L.B. Teixeira, Embrapa Amazônia Oriental, Comum. Técn. 156 (2006).

[14] F.N.A. Abd. Aziz, S.M. Bida, N.A.M. Nasir, M.S. Jaafar, Constr. Build. Mater. 73 (2014) 544.

[15] L.B. Teixeira, J. Furlan Júnior, R.F. de Oliveira, J.B. Bastos, Embrapa Amazônia Oriental, Documentos 71 (2000).

[16] J. Furlan Júnior, L.B. Teixeira, R.F. de Oliveira, R. Dantas, Embrapa Amazônia Oriental, Comum. Técn. 126 (2004).

[17] E. Aprianti, P. Shafigh, S. Bahri, J.N. Farahani, Constr. Build. Mater. 74 (2015) 176.

[18] J. Tay, K. Show, Resour. Conserv. Recy. 13 (1995) 27.

[19] B.S. Thomas, S. Kumar, H.S. Arel, Renew. Sust. Energ. Rev. 80 (2017) 550.

[20] W. Kroehong, N. Damrongwiriyanupap, T. Sinsiri, C. Jarutapitakkul, Arab. J. Sci. Eng. 41, 12 (2016) 4799.

[21] S. Rukzon, P. Chindaprasirt, Int. J. Min. Met. Mater. 16, 4 (2009) 475.

[22] M.Z. Al-Mulali, H. Awang, H.P.S. Abdul Khalil, Z.S. Aljoumaily, Cem. Concr. Compos. 55 (2015) 129.

[23] S.O. Bamaga, M. A. Ismail, Z.A. Majid, M. Ismail, M.W. Hussin, Arab. J. Sci. Eng. 38, 9 (2013) 2293.

[24] D. Adepegba, Mater. Struct. 22, 3 (1989) 220.

[25] I.O. Hassan, M. Ismail, P. Forouzani, Z.A. Majid, J. Mirza, Constr. Build. Mater. 64 (2014) 253.

[26] N.H.A.S. Lim, M.A. Ismail, H.S. Lee, M.W. Hussin, A.R.M. Sam, M. Samadi, Constr. Build. Mater. 93 (2015) 29.

[27] M.R. Karim, H. Hashim, H.A. Razak, S. Yusoff, Constr. Build. Mater. 135 (2017) 21.

[28] NBR NM 52, "Agregado miúdo - determinação da massa específica e massa específica aparente", Ass. Bras. Norm. Téc. (2009)

[29] NBR 5752, "Materiais pozolânicos - determinação do índice de desempenho com cimento Portland aos 28 dias", Ass. Bras. Norm. Téc. (2014).

[30] W. Kroehong, T. Sinsiri, C. Jaturapitakkul, P. 
Chindaprasirt, Constr. Build. Mater. 25 (2011) 4095.

[31] J.H. Filho, A. Gobbi, E. Pereira, V.A. Quarcioni, M.H.F. Medeiros, Rev. Matér. 22, 3 (2017).

[32] NBR NM 248, "Agregados - determinação da composição granulométrica”, Ass. Bras. Norm. Téc. (2003). [33] NBR 7211, "Agregados para concreto - especificação", Ass. Bras. Norm. Téc. (2009).

[34] NBR 13276, “Argamassa para assentamento e revestimento de paredes e tetos - preparo da mistura e determinação do índice de consistência", Ass. Bras. Norm. Téc. (2016).

[35] NBR 9778, "Argamassa e concredo endurecidos determinação da absorção de água, índice de vazios e massa específica”, Ass. Bras. Norm. Téc. (2009).

[36] NBR 13279, "Argamassa para assentamento e revestimento de paredes e tetos - determinação da resistência à tração na flexão e à compressão", Ass. Bras. Norm. Téc.
(2005).

[37] NBR 7215, "Cimento Portland - determinação da resistência à compressão", Ass. Bras. Norm. Téc. (1996).

[38] V.A. Coelho, C.C. Guimarães, in Anais IV Reun. Anual Ciê.,, Tecn., Inov. Cult. Recônc. Bahia: Educ., Desenv. Integ. Soc., Ed. UFRB, Bahia (2017) 936.

[39] Ø. Hammer, D.A.T. Harper, P.D. Ryan, Palaeontol. Electron. 4, 1 (2001) 9.

[40] A.L. Castro, V.C. Pandolfelli, Cerâmica 55, 333 (2009) 18.

[41] J.B.M. do Carmo, K.F. Portella, Cerâmica 54, 331 (2008) 309.

[42] W. Tangchirapat, C. Jaturapitakkul, P. Chindaprasirt, Constr. Build. Mater. 23 (2009) 2641.

[43] V. Sata, C. Jaturapitakkul, K. Kiattikomol, J. Mater. Civil Eng. 16, 6 (2004) 623.

(Rec. 15/08/2018, Rev. 18/01/2019, Ac. 06/02/2019) 